\title{
Reality of Hypertensive Patients from the Uruguay River Coast Assisted by Specialists in Cardiology (Río Uruguay Registry I)
}

\author{
Realidad de los pacientes con hipertensión arterial de la costa del río Uruguay asistidos por \\ especialistas en cardiología (Registro Río Uruguay I)
}

EZEQUIEL HERNÁN FORTE (D), ANA CONSTANZA LAGOS, CARLOS PEDROZA, EZEQUIEL SCHNYDER, FEDERICO GRAZIANO, JUAN NAVARRO

\begin{abstract}
Background: Hypertension is one of the main factors that increase the "burden" of atherosclerotic disease.

Objective: The aim of this study was to analyze the characteristics, treatment and degree of control in patients treated by cardiologists in our area of influence.

Material and methods: A cross-sectional study was carried out in 13 cardiology offices analyzing hypertensive patients' clinical characteristics, blood pressure and pharmacological treatment.

Results: A total of 519 patients with the following characteristics were enrolled during a 3-month period: $44.9 \%$ were men, mean age was 61.5 years, the spell of hypertension was 11.2 years, $24 \%$ of patients had cardiovascular disease and mean blood pressure was 133/79.8 mmHg. Among patients without cardiovascular disease, $73 \%$ had low cardiovascular risk $(<10 \%)$. Hypertensive treatment showed that $39.1 \%$ of patients were receiving two drugs, $26.8 \%$ three, $24.7 \%$ one, $7.9 \%$ four and $1.35 \%$ five drugs. Finally, $60.5 \%$ of patients was within the target blood pressure $(<140 / 90 \mathrm{mmHg})$.

Conclusions: Hypertensive patients evaluated in our geographical area presented low cardiovascular risk and high use of pharmacological combinations. Pressure targets were achieved in $60 \%$ of cases.
\end{abstract}

Keywords: Hypertension - Argentina / epidemiology - Risk factors

\section{RESUMEN}

Introducción: La hipertensión es uno de los principales factores que aumentan la "carga" de la enfermedad aterosclerótica.

Objetivo: Analizar las características, el tratamiento y el grado de control en pacientes atendidos por cardiólogos en nuestra zona de influencia.

Material y métodos: Se realizó un estudio transversal en 13 consultorios de cardiología donde se analizaron las características clínicas, tensión arterial y tratamiento farmacológico.

Resultados: Se enrolaron 519 pacientes en 3 meses, hombres: 44,9\%, edad: 61,5 años, tiempo de hipertensión: 11,2 años, enfermedad cardiovascular: $24 \%$, tensión arterial promedio: 133/79,8 $\mathrm{mmHg}$. Entre los pacientes sin enfermedad cardiovascular, el $73 \%$ tenían riesgo cardiovascular bajo (<10\%). El 39,1\% recibía dos drogas; el 26,8\%, tres; el 24,7\%, uno; el 7,9\% cuatro; y el 1,35\%, cinco drogas. Finalmente, el 60,5\% de los pacientes estaba en el objetivo de tensión arterial $(<140 / 90 \mathrm{mmHg})$.

Conclusiones: Los pacientes con hipertensión evaluados en nuestra área geográfica presentaban bajo riesgo cardiovascular y alto uso de combinaciones farmacológicas. El 60\% alcanzaban los objetivos de tensión arterial.

Palabras clave: Hipertensión arterial - Argentina /epidemiología - Factores de riesgo

Abbreviations

BP Blood pressure

CVD Cardiovascular disease

\section{INTRODUCTION}

Cardiovascular disease (CVD) is still one of the leading causes of death in mid-income countries; (1) in turn, hypertension (HTN) is one of the main factors increasing the "burden" of atherosclerotic disease.
HTN Hypertension

SAC Argentine Society of Cardiology 
is governed by a highly segmented and fragmented health system, which leads to a significant disparity of care in different regions. (6) There are no data on the control of blood pressure (BP) on the coast of the Uruguay River in the Province of Entre Ríos. We consider it of utmost importance that the regional districts of the Argentine Society of Cardiology (SAC) promote cross-sectional studies to understand the reality of our area.

The aims of this study included the analysis of the clinical characteristics, treatment modalities and degree of BP control in patients with history of HTN treated by cardiologists on the coast of the Uruguay River (Province of Entre Ríos).

\section{METHODS}

A cross-sectional study was conducted in 13 cardiology offices of the SAC Río Uruguay District, in the departments of Federación, Concordia, Villaguay, Gualeguaychú and Concepción del Uruguay (map 1). Patients over 18 years of age, with a history of HTN of more than 3 months of evolution, attending the cardiology office in odd numbers (1st, $3 \mathrm{rd}, 5$ th, etc.) for three months were included in the study. Blood pressure was controlled with digital sphygmomanometers on 3 occasions according to the recommendation of the latest SAC HTN consensus, and the mean of the last two measurements was recorded. In addition, history of CVD, medication and anthropometric measurements were completed. The WHO cardiovascular risk score was calculated in patients between 40 and 80 years of age without CVD. In addition, the Morinsky Green adherence test and a low sodium diet adherence questionnaire were administered. "Adequate blood pressure control" was defined as reaching the therapeutic goal $<140 / 90 \mathrm{mmHg}$ according to the SAC consensus. (7)

Statistical analysis

EpiInfo was used to analyze the data. Means, medians,

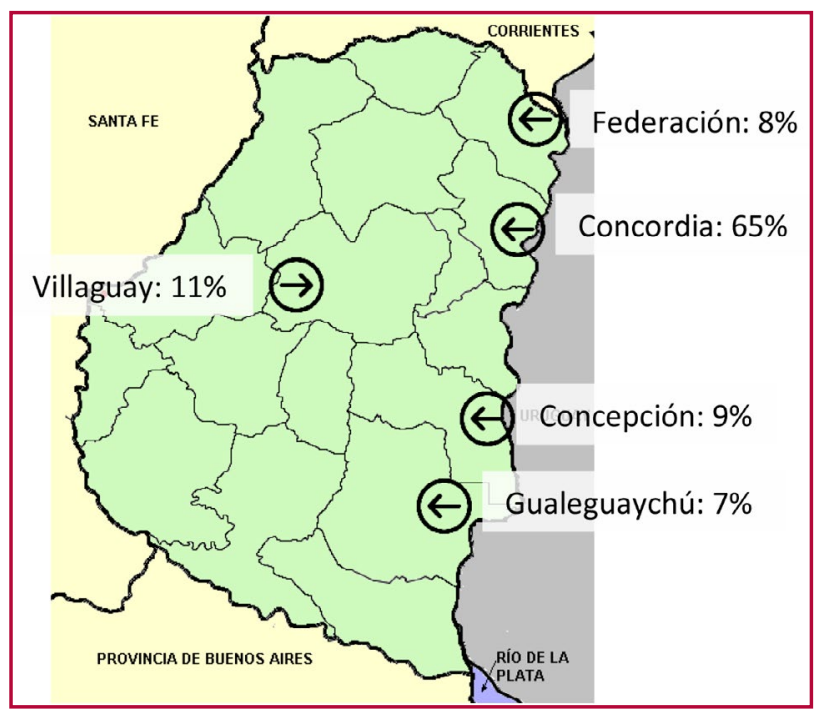

Map 1. Departments of the province of Entre Ríos that participated in the study (\% of patients included). standard deviations and interquartile ranges were used as appropriate. Student's t test was used to compare means and the chi square or Fisher's tests for dichotomous variables.

\section{Ethical considerations}

This study was carried out with the approval of the SAC research area. No personal data that could identify the patient was collected. No procedures or studies were required beyond a regular medical office consultation.

\section{RESULTS}

A total of 519 patients were included in the study: 233 $(44.9 \%)$ were men, mean age was $61.5 \pm 12$ years, the spell of HTN was $11.2 \pm 9$ years (median 10), BMI was 29.4 (19-47), and mean BP was 133/79.8 mmHg. Three hundred and fifty-five patients $(68 \%)$ had abdominal obesity, $22(4.2 \%)$ were current smokers, 87 (16.8\%) were diabetic, $267(61.4 \%)$ had dyslipidemia, and $124(24 \%)$ had CVD. Among patients without CVD, the WHO cardiovascular risk score calculated in 364 patients showed that $73 \%$ had low risk $(<10 \%)$, $19.5 \%$ intermediate risk (10\%-20\%); $4.6 \%$ high risk $(20 \%-30 \%)$ and $2.2 \%$ very high risk $(>30 \%)$.

Women had lower BP, as well as lower smoking habits, but higher abdominal obesity and sedentary lifestyle (Table 1).

Among the different age groups $(<34,35 / 45,46 / 54$, $55 / 65$, and $>65$ years) no statistically significant differences were observed in achieving the therapeutic objective (Figure 1).

Thirty-six per cent of patients adhered to a low sodium diet and $72 \%$ to pharmacological treatment. Use of drugs and their combinations showed that 379 patients $(70.7 \%)$ were receiving angiotensin receptor blockers (ARBs), 248 (50.1\%) beta-blockers (BB), 219 (42.9\%) calcium channel blockers (CCB), $192(39.1 \%)$ diuretics (Diur), 93 (19.8\%) angiotensin converting enzyme inhibitors (ACEI) and 31 (6.4\%) antialdosterone agents (AA). No significant differences between sexes were found in the use of antihypertensive drugs, except for ACEI that were less used in women (p: 0.04) (Figure 2). Regarding the number of drugs, $39.1 \%$ of patients were receiving two drugs; $26.8 \%$ three drugs; $24.7 \%$ one drug; $7.9 \%$ four drugs; and $1.35 \%$ five drugs. The most frequently used combination was $(\mathrm{ARBs} / \mathrm{ACEI})+$ Diur in $17.3 \%$ of cases, followed by $\mathrm{ARBs} / \mathrm{ACEI}+\mathrm{CCB}$ in $14.1 \%$, triple combination of $\mathrm{ARBs} / \mathrm{ACEI}+\mathrm{Diur}+\mathrm{CCB}$ in $11.4 \%$ and $\mathrm{BB}+$ Diur in $2.3 \%$ of patients.

\section{DISCUSSION}

The registry provides, for the first time, regional data on hypertensive patients, their characteristics, therapeutic management and degree of control achieved. We observed a population mostly with no history of CVD, with a high rate of abdominal obesity and low clinical risk ( $74 \%$ with $<10 \%$ cardiovascular risk). Mean blood pressure $(133 / 79.8 \mathrm{mmHg})$ was slightly lower than 
Table 1. Patient distribution according to preestablished intervals from onset of symptoms to admission.

\begin{tabular}{|lcccc|} 
& Total & Men & Women & p \\
\hline $\mathrm{SBP}($ mean \pm SD) & $133.5 \pm 15$ & $135 \pm 14,4$ & $131.9 \pm 15.9$ & 0.002 \\
\hline $\mathrm{DBP}($ mean $\pm \mathrm{SD})$ & $79.8 \pm 9.9$ & $81.3 \pm 10.9$ & $78.6 \pm 8.9$ & 0.002 \\
\hline Smoking, $\mathrm{n}(\%)$ & $22(4.2)$ & $17(7.3)$ & $5(1.7)$ & 0.001 \\
\hline Diabetes, $\mathrm{n}(\%)$ & $87(16.8)$ & $43(18.4)$ & $44(15.4)$ & 0.1 \\
\hline Dyslipidemia, $\mathrm{n}(\%)$ & $267(61.4)$ & $124(53)$ & $143(50)$ & 0.2 \\
\hline Sedentarism, $\mathrm{n}(\%)$ & $118(22.7)$ & $44(18.9)$ & $74(25.9)$ & 0.02 \\
\hline Abdominal obesity, $\mathrm{n}(\%)$ & $355(68)$ & $135(57)$ & $220(76)$ & 0.001 \\
\hline
\end{tabular}

Fig. 1. Target blood pressure achieved by age group

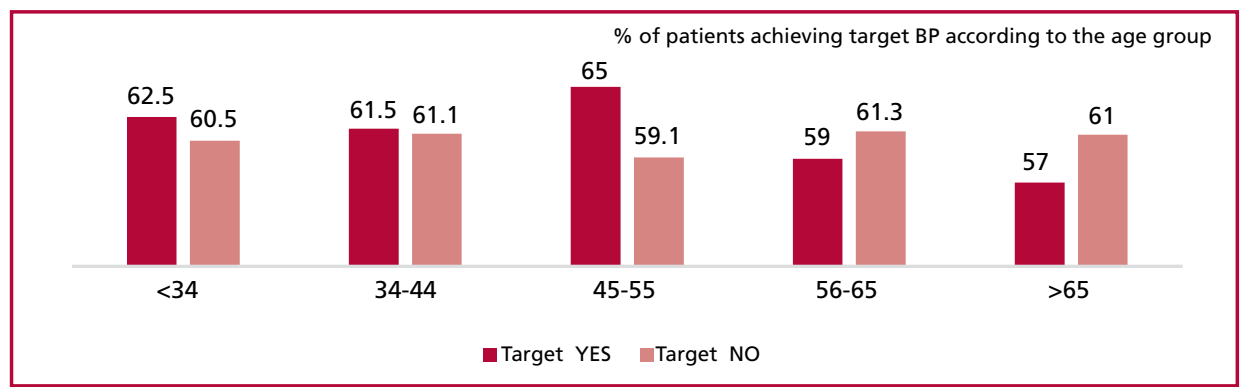

Fig. 2. Drugs used according to gender (\%)

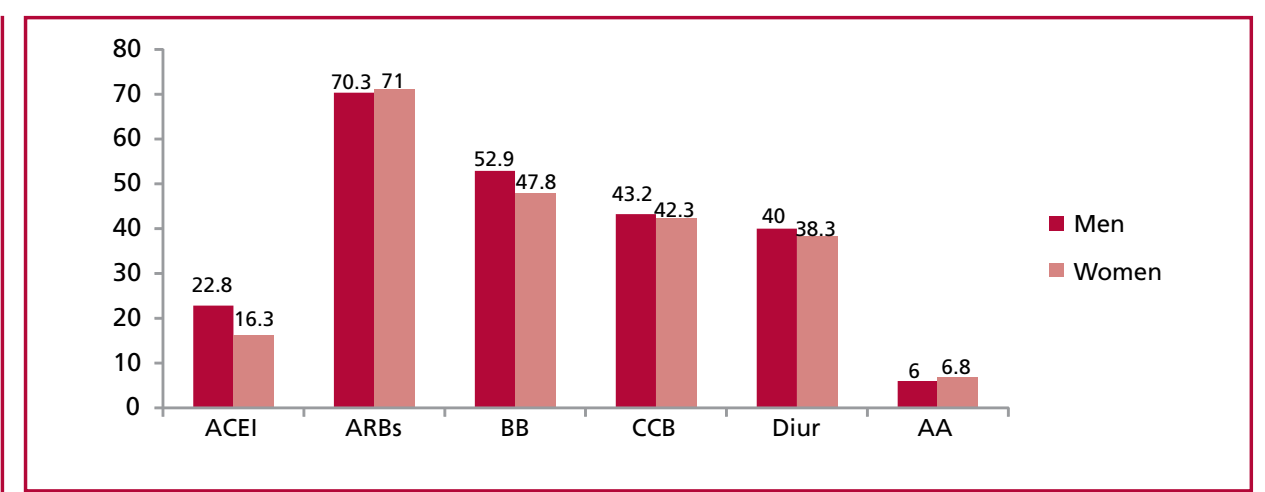

that observed in the Argentine PURE study (135/82.8 $\mathrm{mmHg}$ ). (8) Adherence to treatment was high compared to the ENSAT study, which was only of $48.5 \%$. (9) On the other hand, only 1 in 4 patients adhered to a low sodium diet. We observed a high use of ARBs over ACEI, with frequent use of a combination of two or more antihypertensive drugs well above the RENATA 2 study, where use of a combination of drugs was found in less than a third of the studied population. (4) Women had a lower level of systolic and diastolic $\mathrm{BP}$, lower smoking habits and higher obesity, although these characteristics were not reflected in the achievement of the therapeutic target, which had no statistical significance. We also found a better BP control in the age group of 45-55 years, although this difference was neither statistically significant in target attain- ment, possibly due to the low number of patients.

Regarding BP control, $60 \%$ of the patients achieved the therapeutic target which was higher than that of other registries, such as the CardioTens study (Spain), with $55.4 \%$ of patients, (10) the RENATA 2 registry with $29 \%$, or the study by Rubinstein et al. with $43.3 \%$, (11) possibly due to the large difference between the populations studied. Nevertheless, $40 \%$ of the patients treated by cardiologists did not attain the therapeutic goals.

\section{CONCLUSIONS}

Patients with HTN evaluated in our geographic area, showed low-risk characteristics, with a high use of pharmacological combinations and with $60 \%$ of patients meeting the therapeutic target. 


\section{Conflicts of interest}

None declared.

(See authors' conflicts of interest forms on the website/ Supplementary material)

\section{REFERENCES}

1. Yusuf S, Joseph P, Rangarajan S, Shofiqul I, Andrew M, Perry $\mathrm{H}$ et al. Modifiable risk factors, cardiovascular disease, and mortality in 155722 individuals from 21 high-income, middle-income, and low-income countries (PURE): a prospective cohort study. The Pure Study. Lancet 2019;3:1-14. http://dx.doi.org/10.1016/S01406736(19)32008-2

2. Stephen S, Vos T, Flaxman A, Danaei G, Shibuya K, Adair-Rohani $\mathrm{H}$ et al. A comparative risk assessment of burden of disease and injury attributable to 67 risk factors and risk factor clusters in 21 regions, 1990-2010: a systematic analysis for the Global Burden of Disease Study 2010. Lancet 2012; 380:2224-60. http://dx.doi.org /10.1016/S0140-6736(12)61766-8

3. Marin MJ, Fábregues G, Rodríguez PD, Díaz M, Páez O, Alfie J et al. National Registry of Hypertension. Awareness, Treatment and Control of Hypertension. The RENATA Study. Rev Argent Cardiol 2012;80:121-9.

4. Delucchi A, Majul C, Vicario R, Cerezo G, Fábregues G. National Registry of Hypertension. Epidemiological Characteristics of Hypertension in Argentina. The RENATA 2 study. Rev Argent Cardiol
2017;85:354-60. http://dx.doi.org/10.7775/rac.es.v85.i4.11061

5. Echeverría RF, Camacho RO, Carbajal HA, Salazar H, Mileo N, Rionde B y cols. Conocimiento y tratamiento de la hipertensión arterial en La Plata, Argentina. Medicina (B. Aires) 1989;49:53-8.

6. Arce HE. The Argentine Health System: Organization and financial features. Medicina (B. Aires) 2012;72:414-8.

7. Giunta G, Abreu M, Peralta S, Procopio G, Giorgi M, Galli M y cols. Consenso Argentino de Hipertensión Arterial. Rev Arg Cardiol 2018;86(Supl. 2):1-49. https://www.sac.org.ar/wp-content/uploads/2018/08/consenso-argentino-de-hipertension-arterial-2018.pdf

8. Chow C, Teo K, Rangarajan S, Islam S, Gupta R, Avezum A, et al. Prevalence, Awareness, Treatment, and Control of Hypertension in Rural and Urban Communities in High-, Middle-, and Low-Income Countries. JAMA 2013;310:959-68. http://dx.doi.org/10.1001/ jama.2013.184182.

9. Ingaramo R, Vita N, Bendersky M, Arnoldt M, Bellido C, Piskorz D y cols. Estudio Nacional Sobre Adherencia al Tratamiento (ENSAT). Rev Fed Arg Cardiol 2005;34:104-11. http://www.fac.org.ar/1/ revista/05v34n1/hta/ingaramo.pdf

10. Cordero A, Bertomeu-Martínez V, Mazon P, Facial L, BertomeuGonzález V, Cosin J y cols. Factores asociados a la falta de control de la hipertensión arterial en pacientes con y sin enfermedad cardiovascular. Rev Esp Cardiol 2011;64:587-93.

http://dx.doi.org/10.1016/j.recesp.2011.03.008

11. Rubinstein A, Irazola E, Calandrelli M, Chen CS, Gutiérrez L, Lanas F, et al. Prevalence, Awareness, Treatment, and Control of Hypertension in the Southern Cone of Latin America. Am J Hypertens 2016;29:1343-52. http://dx.doi.org/10.1093/ajh/hpw092 